\title{
Design for design - design by community
}

\author{
Thi Hanh Nguyen Nguyen ${ }^{1, *}$ \\ Architectural University of Ho Chi Minh City, 196 Pasteur, Ward 6, District 3, HCMC, Ho Chi Minh, \\ Vietnam
}

\begin{abstract}
Like many other countries in the world, Vietnam is facing the problem of housing for the poor. Though, a lot of money and effort have been poured into these projects, but often it falls into a very bad situation, which is unstable: the community rapidly come back to poverty, people cannot self-recover and develop on their own after withdrawal of project teams, ect. In the field of Architecture and Planning, there is a fairly common method, which is "participatory methods". But by failing to understand the essence and not knowing how to operate the method in practice, the projects for the poor have little success. This paper introduces the following two areas: The Community "Participation Design" concept we have just implemented in a poor neighborhood of Tam Ky, Vietnam. Through the lessons of Tam Ky, the shift of participation concept is summarized: from passive to active community. In this way, the Community initiates and implements its initiative to change its habitat, make it better and more sustainable.
\end{abstract}

\section{Introduction}

Recent community trends have contributed to the direct, active engagement in local development plans, which has brought about positive and far-reaching effects. The community is directly affected and most aware of the issues and needs of the area where they live, so they can contribute effectively to improving the environment. The essence of "Design for the community" is "involvement," but not every architect or researcher has the right approach. They often impose "specialized" thought and have their own wills on the project's part. Even some of the projects that won the "design for the community" are now in the state of being: mostly designed in the subjective thinking of the architect without proper "involvement" from the public. In other words, that is just the way we do charity, or give the local a design product that fits our own, professional, and artistic vision. This product was initially expected to work for the community, but it did not really come from the desire of the community and therefore, it became quite alienated to the public [1].

According to our current observations, architects have been attaching great importance to the construction of facilities, giving very logical designs. Meanwhile, the poor has more to concern about, what they worry about is how to stabilize their lives and improve their financial income. So the products that architects create for them really called "design for the community" or not. We affirm that in order to achieve the objective of improving the living

\footnotetext{
*Corresponding author: nguyenhanhnguyen.kts@gmail.com
} 
conditions of the poor neighborhoods, the ORIENTATION will be more suitable than the installation.

From this point of view, we have developed the idea for a study: "Community-based ecotourism development project in Tam Thanh, Tam Ky". The purpose of the project is to enhance the active role of local people in freeing themselves from poverty and building a stable life. We have come up with the right approach for people to participate, from the very beginning and play a key role in the idea, handling, organizing and managing the results of the project. Professionals, managers only play a role in guiding and providing the knowledge to help them realize their own "problem" [2, 3].

The project has gone through stages: Problem Detection, Concept Building and Construction Implementation. These phases are applied to the "Co-doing" method (Coanalysis, Co-design, Co-implementing).

\section{Literature review}

To argue for our own researches, we would like to mention the documents related to the "design for community" issue:

"Improving the environment in poor communities around Lang Son City based on Community Development Funds. "Master thesis in Environmental Science,National University of Science of Hanoi (2011) by Nguyen Thi Thinh. With the aim of assessing the effectiveness of environmental improvement in poor communities based on community development funds, find solutions to increase the effectiveness of environmental management programs in poor neighborhoods (the two poorest villages are Quang Lac and Hoang Dong [4]. The study aims to harmonize poverty reduction and sustainable development. Although this document is in the field of management and the environment, not architecture, but it helps architects who study and work in the field of poverty alleviation understand how a community approach is effective [5].

"Why it must be different", presentation by Le Dieu Anh at the Workshop on Community Development Project in Tam Ky, Quang Nam, November 2016, called out the meaning of "participation" and the correct understanding of "Participation of the community" in the project.

“ACHR Community Mapping for Housing by Peoples Process Handbook", Community Organizing And Participation Secretariat, Bangkok, Thailand, 2011.This report summarizes how the planning and architecture process works together with the community. This is the study of the application of theories of value to be able to do case studies for urban Vietnam [6].

"Building an urban poor people's movement in Phnom Penh", Cambodia (2011). This is documented on the environment and urbanization of Cambodia. The article shows how poor communities can access non-governmental and foreign donors to implement local poverty reduction: improving the quality of housing, and surrounding environment, borrowing money, and raising funds for the poor, etc.

"Rebuilding Lives and Homes in Aceh and Nias', edited by Florian Steinberg and Pieter Smidt, Indonesia, Urban Development Series, ADB. (2010). The book focuses on housing, one of ETPS's most sub-objectives in a poor Indonesian locality and shows that the housing program for the poor is a dynamic learning experience [7, 8].

"Outcomes-map-Housing-and-essential-needs", by Sally Bagwell, New Philanthropy Capital, London (2013). This report examines issues of access to housing, housing standards, suitability of housing for those with additional needs, and support with the skills necessary to maintain the home. With the participation of the local community.

"Community organizing and participation, is a project implementation report that outlines the principles of community organizing and participation in project implementation." This is 
seen as a way for stakeholders to influence development by contributing to project design. It is important to understand that direct participation must be directly addressed by affected groups in the project cycle, project design, implementation, and monitoring [9].

"Celebrating the Phu Xuan spirit", report on Participatory action research, Ho Chi Minh city, Vietnam."This 2016 project report is a very detailed analysis of the community-based process and methodology of action research. A poor community in Ho Chi Minh City has been involved with university experts and students(Van Lang, Ho Chi Minh City University of Technology, Singapore Design and Technology University) implementing environmental improvement projects. One of the most obvious results is the construction of a playground for children. However, in this project, the people do not participate in the final stage: credit and construction (ie, funding and labor are provided by the project). Due to the lack of community participation in the construction phase, there is a lack of impact in community life.

In addition to the references cited above, some of my own research also has a definite meaning as a process of finding practical approaches:

Report on the theme "Self-built dwelling house in Hanoi's Old Quarter",report on the "Urban Poverty Elimination" short-course at the Institute for Housing Research (IHS), Rotterdam, Netherlands in 1999, Nguyen Thi Hanh Nguyen. The basis for future research on how to approach the poor to build their houses has been carried out in the basic steps of surveying, planning and construction. However, the process of learning about the community's life for the design takes place only at the site analysis stage without the people being consulted until the final stage. Both the budget for the implementation and the budget allocated by the State budget (there was no "State and people" concept at the time. Because the project is so far away from the people, they do not care about it, the way to deal with the "everyone business" has led to a very rapid degradation of the buildings.) [10].

The article "Hanoi Women involed in the "Green, Clean and Beautiful City" movement" presented in workshop "Women's Studies Asian Connections, at the University of Calgary, Canada (2000) by Nguyen Thi Hanh Nguyen pointed to the benefits of appealing to the community, especially children and women, The movement to preserve the green - clean nice city. However, this movement is limited to environmental cleanup activities (within the urban management area) rather than to the urban space structure for low-income people in urban areas. Presentation on "Resettlement for Hanoi's Old Quarter" by Nguyen Thi Hanh Nguyen, International Conference on "Architecture and Urbanism of Vietnam" at Seoul National University, Korea (2005). This article has described the resettlement solution for the households located in the old quarter, the site is located in the heart of the ancient Hanoi but has very low living conditions. This study shows clearly the views of the planning designers who are imposing people into the new urban area (Viet Hung urban area) across the river, out of the city center. The project did not mention the people's livelihood after moving to new housing. A high-rise apartment design completely ignores the habits, lifestyles and working environment of the people.

Recent scientific papers published in the Vietnam Architecture Association's "Architecture for the Community" workshop in December 2016, Nguyen Thi Hanh Nguyen wrote the ACCA Project (2014) in the area. Binh Dong 1 Street, Ward 3, Tan An City, Long An Province, by a group of architects for community. Context of poor self-reliance neighborhoods living on public land and along canals, no clean water; no electricity, polluted environment, temporary housing (sheltered with temporary materials), unstable working population, insecure income, no household registration, no identification, ect. The people here fall into a vicious circle: spontaneous encroachment - Relieved - Relocate - Reuse spontaneously. This project is highly valued for its effectiveness, sustainability and positive impact on the community. Although the image of works does not really reach the aesthetic value metrics, these spaces are very humanistic, very close, because it comes from real needs, 
from aspirations and the feelings of the people [11]. The key solutions are: Community-based design, planning options, setting up credit funds for construction, public utilities construction are well suited to the people. The success of this project prompted the research team to carry out the next Tam Ky project (from June, 2016 to June, 2017), which is covered in this article.

"Community design factors and their influence on physical activity in the aging population: A Rapid Review" by Simone Kaptein, Sandra Almeida and Sharanjeet Kaur (2016): This document has clarified the connection between community design elements and physical activity behaviors in older adults. Some factors mentioned in this documents are pedestrian infrastructure, safety from traffic and crime, access to public transit, street length, slopes and stairs, etc. However, although it is called a community project but it is still based on others' experiences and researches; no interviews, surveys or field researches were conducted by the authors. This leads to the fact that the research and the real needs of the community are not met. Their design was still FOR the older people, not BY the older people. In our project, we do not just study the available material and apply our design to the community. We let the people make their choices [12].

Technical report "A literature review on community and institutional preparedness synergies: Enablers and barriers in community and institutional preparedness effectively working together globally and specifically within the EU/EEA” by Anna Ramsbottom, Elly O'Brien, Massimo Ciotti, Judit Takács (2017). This literature review emphasized the importance of community ownership in engagement techniques. All community members must acknowledge that they have a role to play in emergency preparedness. This also applies to community design. In our project, we ensured that voices of people from all seven villages of Tam Thanh commune are heard, although the design had just been applied in 3 villages.

\section{Materials and methods}

Poor communities are the ones most at risk when faced with the negative effects of urban economy and society impacts. Poor communities are also disadvantaged in terms of their contaminated cultural environment, their impact on their health and their livelihoods. Poor living conditions keep them from facing disease, no escape. Housing projects for urban poor communities usually comprise of the following steps:(1) Identifying the core issues facing the community, (2) Impacts to changing perceptions and living conditions, and (3) Maintain and operate well so that the community continues to grow.

Basically, these steps are similar between different projects. However, the lessons learned from previous researches show us that, despite our efforts we have not changed much. The projects often occurred in a short duration, mainly due to the lack of funding and inapproriate approaches.

\subsection{Context}

Tam Thanh commune (Tam Ky, Quang Nam) is a poor coastal commune in the Central Vietnam with more than 3000 people spread across 7 villages. The commune has special geographic features: It is $3 \mathrm{~km}$ long from north to south, one is bordered by East Sea, one is bordered by Truong Giang River. The waist stretches the river and the sea only one way (Thanh Nien Road). Tam Thanh has the main occupation of the fishermen is fishing, income uncertain. Early in 2016, "Tam Thanh murals" born. This is a collaboration between Tam Ky City and Korea's Koria Foundation. (Of the 7 villages Trung Thanh village is located in the middle of the commune selected for this project.) Initially, some visitors came to Tam Thanh but there are no facilities to keep visitors. Travel services are very basic (only basic services start to form: cars, water). The problem of sustainable tourism for development is posed. How to make people in 7 villages benefit, how to keep visitors longer? From the request of 
the City Government, from the context of Tam Thanh, we have developed the idea for a new project: "Community-based ecotourism development project in Tam Thanh, Tam Ky".

Community design often targets poor areas as the primary target audience. But what is the main problem of a poor community? Where do they need us to help them to change?

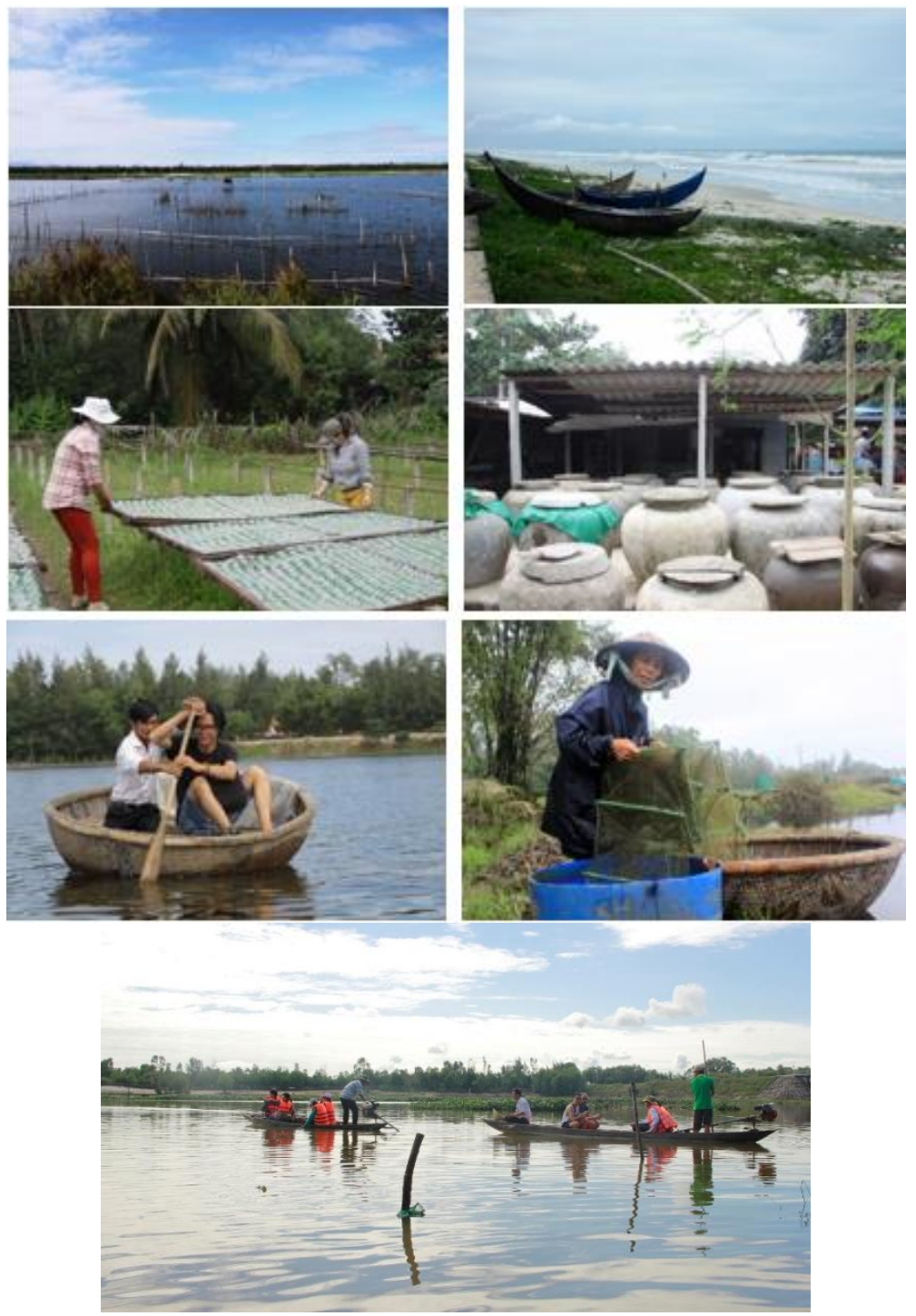

Fig. 1. Discover the core values of Tam Thanh.

The main subject that the project targeted is the people, all activities of the project revolve around the people. We have studied and analyzed deeply about nature and society. Discover Tam Thanh potential: There are $7 \mathrm{~km}$ coastline with white smooth sand, suitable for swimming and resting activities. Tam Thanh has a very unique geographic and ecological characteristic: a village on the sea side, a river side with a very wild landscape. Human resources: Peaceful people, still retain the historical value and many traditional culture, unique region. Rich cuisine is exploited from the sea's available produce that many people can make, ect. The volunteer team was formed, initially consisting of more than 30 people, 
including experts in urban and community development, architecture, planning, landscape and student affairs from 5 universities in HCMC and Da Nang. Later in the project, the number of volunteers increased gradually to 60 members and more than 130 volunteers from various fields assisted. Taking ownership of people, the active participation of people is the key of the project. With this view, from the very first steps of the project we have set the goal: Any tourism product must be simple for the people to achieve, Any tourism product must be simple for the people to achieve, the results of the project must be to create livelihoods and increase incomes for people, not to break traditions, habits and deformation the environment.

\subsection{Stages}

In order to achieve harmony and sustainable development goals, architects should take the appropriate approach, transform the poor's position from being a "beneficiary" (They are involved from the beginning and play a key role in the idea, handling, organizing and managing the results. Architects or professionals, managers should play the role of guiding, orienting, and providing the knowledge and tools to assist them in implementing their "problem". The project has gone through stages: survey, problem discovery, workshops: workshop 1 with co-analysis, training and workshop 2: co-design and workshop 3: coimplementing.

Table 1. Community participation in project phases.

\begin{tabular}{|c|c|c|c|c|c|c|c|c|}
\hline & & STAGES & $\begin{array}{l}\text { People in } \\
\text { Commun } \\
\quad \text { ity }\end{array}$ & $\begin{array}{l}\text { Commun } \\
\mathrm{e} \\
\text { authoritie } \\
\mathrm{s}\end{array}$ & $\begin{array}{c}\text { City } \\
\text { Governmen } \\
\mathrm{t}\end{array}$ & $\begin{array}{c}\text { Project } \\
\text { Steering } \\
\text { Committe } \\
\mathrm{e}\end{array}$ & $\begin{array}{l}\text { Expert } \\
\mathrm{s}\end{array}$ & $\begin{array}{c}\text { Universit } \\
\text { y } \\
\text { students }\end{array}$ \\
\hline 1 & \multirow{2}{*}{\multicolumn{2}{|c|}{$\begin{array}{l}\text { Survey, potential detection } \\
\text { Preparing the project, } \\
\text { recruiting students to } \\
\text { participate }\end{array}$}} & $\mathrm{X}$ & $\mathrm{X}$ & $\mathrm{X}$ & $\mathrm{X}$ & $\mathrm{X}$ & \\
\hline 2 & & & & & & & $\mathrm{X}$ & $\mathrm{X}$ \\
\hline \multirow[t]{4}{*}{3} & \multirow{4}{*}{ 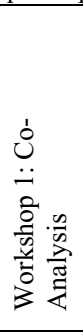 } & $\begin{array}{l}\text { Capacity } \\
\text { training }\end{array}$ & & & & $\bar{X}$ & $\bar{X}$ & $\mathrm{X}$ \\
\hline & & $\begin{array}{l}\text { Field } \\
\text { survey }\end{array}$ & & $\mathrm{X}$ & $\mathrm{X}$ & $\mathrm{X}$ & $\mathrm{X}$ & $\mathrm{X}$ \\
\hline & & $\begin{array}{l}\text { Understanding } \\
\text { community } \\
\text { requirements }\end{array}$ & $\bar{X}$ & $\mathrm{X}$ & & $\mathrm{X}$ & $\mathrm{X}$ & $\mathrm{X}$ \\
\hline & & $\begin{array}{l}\text { Meeting, Site } \\
\text { analysispresentati } \\
\text { on }\end{array}$ & $\mathrm{X}$ & $\mathrm{X}$ & $\mathrm{X}$ & $\mathrm{X}$ & $\mathrm{X}$ & $\mathrm{X}$ \\
\hline \multirow[t]{4}{*}{4} & \multirow{4}{*}{ 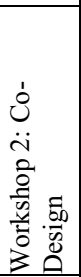 } & $\begin{array}{l}\text { Ideas of Planning } \\
\text { and Landscaping }\end{array}$ & $\mathrm{X}$ & $\mathrm{X}$ & $\mathrm{X}$ & $\mathrm{X}$ & $\mathrm{X}$ & $\mathrm{X}$ \\
\hline & & $\begin{array}{l}\text { Idea of } \\
\text { Architecture }\end{array}$ & $\mathrm{X}$ & $\mathrm{X}$ & $\mathrm{X}$ & $\bar{X}$ & $\mathrm{X}$ & $\mathrm{X}$ \\
\hline & & $\begin{array}{l}\text { Build activity } \\
\text { experience }\end{array}$ & $\mathrm{X}$ & $\mathrm{X}$ & $\mathrm{X}$ & $\mathrm{X}$ & $\mathrm{X}$ & $\mathrm{X}$ \\
\hline & & $\begin{array}{l}\text { Media and } \\
\text { Fundraising }\end{array}$ & $\mathrm{X}$ & $\mathrm{X}$ & $\mathrm{X}$ & $\bar{X}$ & $\mathrm{X}$ & $\mathrm{X}$ \\
\hline \multirow[t]{4}{*}{5} & \multirow{4}{*}{ 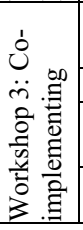 } & $\begin{array}{l}\text { Planning, } \\
\text { Landscaping }\end{array}$ & $\mathrm{X}$ & $\mathrm{X}$ & $\mathrm{X}$ & $\mathrm{X}$ & $\mathrm{X}$ & $\mathrm{X}$ \\
\hline & & Architecture & $\mathrm{X}$ & $\mathrm{X}$ & $\mathrm{X}$ & $\mathrm{X}$ & $\mathrm{X}$ & $\mathrm{X}$ \\
\hline & & $\begin{array}{l}\text { Activity } \\
\text { experience }\end{array}$ & $\mathrm{X}$ & $\mathrm{X}$ & & $\mathrm{X}$ & $\mathrm{X}$ & $\mathrm{X}$ \\
\hline & & Media activities & & $\mathrm{X}$ & $\mathrm{X}$ & $\mathrm{X}$ & $\mathrm{X}$ & \\
\hline
\end{tabular}




\section{Results (obtained from the Tam Ky Project)}

\subsection{Movement of the "Design for the Community" concept:}

In the area of community design, the design trend is gradually shifting from "Design for Community": a completely passive community, to "Design with Community" Community participation in design options and towards the highest level of initiative is "Design by Community": the community actively initiates and implements initiatives. The two following ways are progressive, in line with the sustainable development of the philosophy of "Giving rods, not fish"

This philosophy, this principle has been incorporated into Tam Ky project to make a significant change in the lives of the population. The relity situation had showed that amovement in the method is inevitable. These movements include:

Table 2. Translation of "design for community" concept.

\begin{tabular}{|c|c|c|c|}
\hline \multirow[b]{2}{*}{ Stage } & STAGE 1 & STAGE 2 & STAGE 3 \\
\hline & $\begin{array}{l}\text { Well known in Asia, } \\
\text { Being popular in } \\
\text { Vietnam today. }\end{array}$ & $\begin{array}{c}\text { Several projects are } \\
\text { approaching, achieving } \\
\text { high efficiency }\end{array}$ & $\begin{array}{l}\text { Desired concept, future } \\
\text { concept }\end{array}$ \\
\hline \multirow[t]{2}{*}{ Approach } & $\begin{array}{ll}\text { "Thiết kế cho Cộng } \\
\text { đồng" }\end{array}$ & $\begin{array}{ll}\text { "Thiết kế cùng Cộng } \\
\text { dồng" }\end{array}$ & $\begin{array}{ll}\text { "Thiết } & \text { kế bởi Cộng } \\
\text { đồng" } & \end{array}$ \\
\hline & Design for Community & Design with Community & Design by Community \\
\hline $\begin{array}{l}\text { Nature of } \\
\text { participation }\end{array}$ & $\begin{array}{l}\text { The community is } \\
\text { completely passive }\end{array}$ & $\begin{array}{l}\text { Community participation } \\
\text { in design options }\end{array}$ & $\begin{array}{c}\text { Communities actively } \\
\text { initiate and implement } \\
\text { initiatives }\end{array}$ \\
\hline $\begin{array}{l}\text { Attitude of } \\
\text { Attendance }\end{array}$ & $\begin{array}{l}\text { Architects and } \\
\text { stakeholders are } \\
\text { sympathetic to the } \\
\text { difficulties of the } \\
\text { community }\end{array}$ & $\begin{array}{l}\text { Architects and } \\
\text { stakeholders have a } \\
\text { shared attitude towards } \\
\text { the community, building } \\
\text { relationships and building } \\
\text { trust in the community. }\end{array}$ & $\begin{array}{l}\text { Every member of the } \\
\text { project must understand } \\
\text { the community, } \\
\text { enthusiasm, } \\
\text { responsibility, } \\
\text { enthusiasm, harmony } \\
\text { and cooperation. }\end{array}$ \\
\hline Results & $\begin{array}{l}\text { Immediate impact but } \\
\text { unsustainable } \\
\text { performance, people do } \\
\text { not see the value to } \\
\text { continue to maintain } \\
\text { after the project } \\
\text { withdrew from the } \\
\text { community. }\end{array}$ & $\begin{array}{l}\text { People maintain and } \\
\text { protect project items } \\
\text { because they are "Co- } \\
\text { design" products }\end{array}$ & $\begin{array}{l}\text { People are more active, } \\
\text { more responsible, } \\
\text { continue to maintain and } \\
\text { can invest more to } \\
\text { complete items after the } \\
\text { end of the project. }\end{array}$ \\
\hline
\end{tabular}

In step 2 and step 3, the author implemented a "co-design", a collaborative and participatory design concept. In essence, this is an effective and sustainable concept for community development projects.

The community is the 'owner' - the 'owner', the operator and the manager (maintenance, maintenance). Therefore, the solution to do WITH instead of FOR will bring real effect to the community and change the face of the residential area.

The process of community participation will include: Identification of needs - solutions (technical, legal, institutional) - means (finance, organization) - implementation management. The process of negotiation among members of the community can not be the opinion of individual individuals 


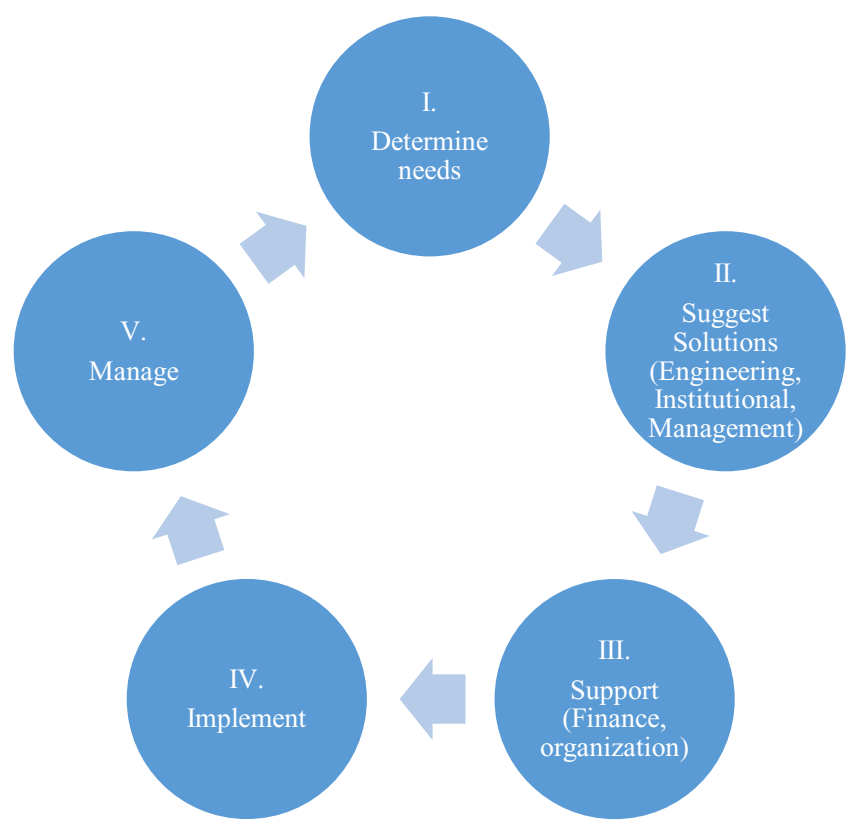

Fig. 2. Complete progress to the community.

In Fig. 1, architects can participate in 3/5 activities, including: I. Determination of needs; II. Suggestion of solutions (this is the strongest support to provide design solutions, which are based on the needs of the community); IV. Implementation.

When helping someone, first listen to people, provoke passion to their desire to do, to be changed. Only then do they really engage with high consciousness, they transform themselves and try to change, the change is then valuable.

\subsection{Unique tourism concept}

The concept that formed in Tam Thanh, for Tam Thanh was later became a unique tourism product, which is a positive result of the project. It includes:

- The art of boats: Artisanizing boats - simple and familiar tools of the people. Volunteers who are famous artists have instructed people to draw on and place 111 boats in empty spacesalong the riverside to create a special landscape for Tam Thanh. The drawings on the boats depicted familiar images with the fishing village of Tam Thanh.

- Non-garbage village: The village now welcomes tourists, since then only the Thanh Nien road (road of Youth) the main road of the village is stay clean, the others and the coast have a lot of rubbish. Garbage is the worst image in the tourist attractions of Vietnam. From the suggestion of a foreign volunteer in the workshop delegation mentioned in Workshop 1, together we have built a very independent and well-supported project. (This project must have the consensus and enthusiastic support of the people can be implemented)

- Village of Flowers: Cactus is a special species of the sea that found in village, people had mixed them with some special flowers to create a peaceful landscape. This landscape is multipled with many other flowers on the background of cactus and make a strong impression. Villagers have registered to plant trees and flowers (which are from the list of options consulted by landscape experts) and pledge to protect them.

- Village stay: Instead of Home stay, a popular concept, here the services of eating, sleeping, resting from the village, not the household. This finding is due to poor people, not 
enough money to hold a home stay, but then they combine their services (bath, sleep, eating , ect. depending on their family circumstances), they are able to make a very good package accommodation.

- Tam Thanh Experience Service: Life on boat and Coastal Biking experience. These two services were created thanks to the formation of two cooperative groups. Boats and bicycles are stuffs that available in households, and people who are accustomed to work will register in a co-operative group to share work and benefit. In addition to the experience of space, natural landscapes, experiential tours associated with local culture and specialties are opened to promote traditional values, promoting the handicraft, which is gradually lost.

- Initially, when the project was put into operation, the project was funded by donors, which was partly deducted from the fund for the poor to help them change their careers.
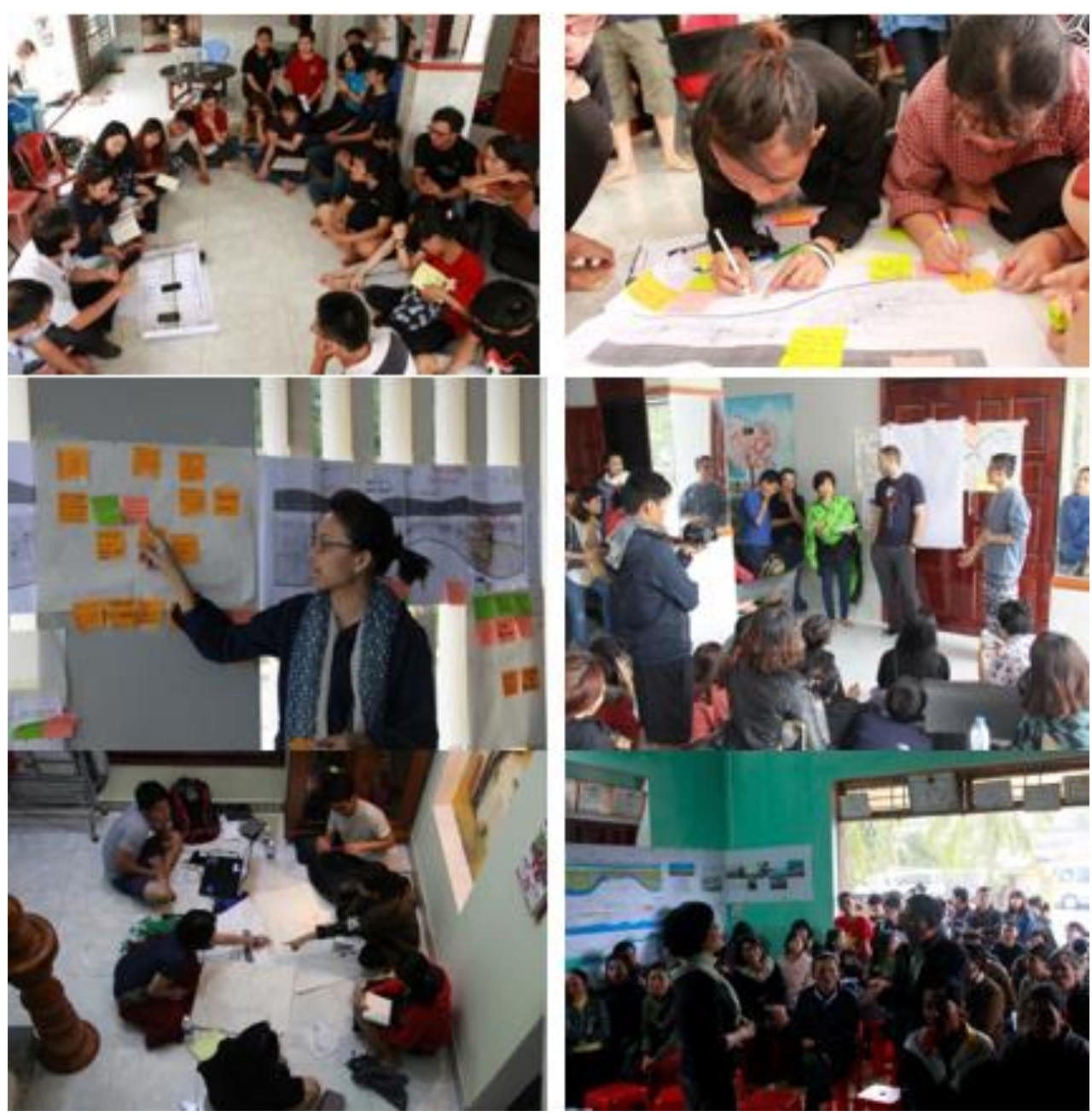

Fig. 3. Co- Analysis of Tam Thanh. 


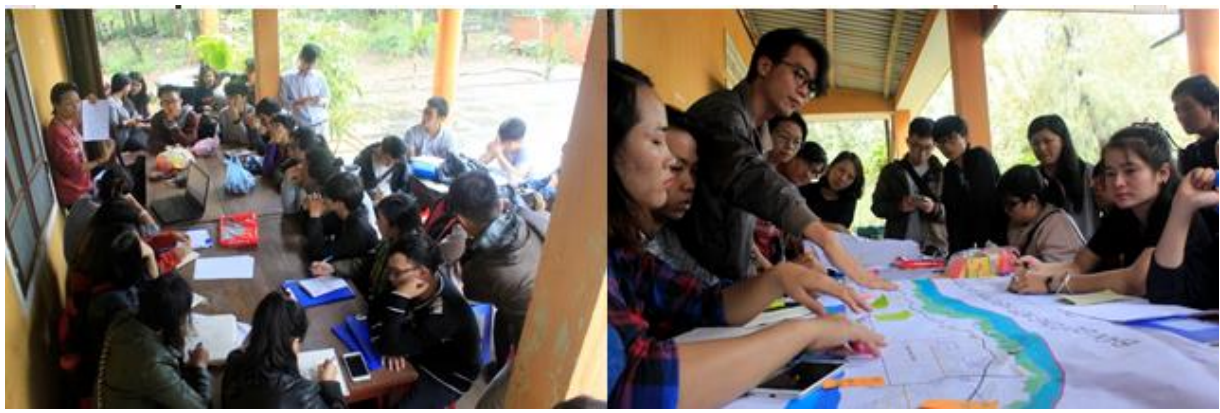

Fig. 4a. Co- Design of Tam Thanh.
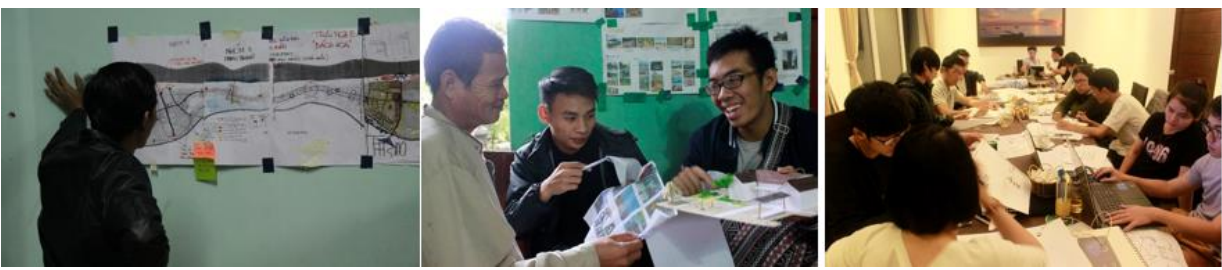

Fig. 4b. Co- Design of Tam Thanh.

\subsection{Facilities catering to the tourism concept}

In service of tourism, some works are designed (co-design, community design) including:

- Reception area: Including greeting gate, parking area, information supply.

- Playground at cultural houses: 7 cultural houses for 7 villages were proposed to renovate the playground.

- Building a cultural house in Trung Thanh village

- Observatory on the river and the sea

- A sustainable concept for Tam Thanh Community Arts Village: The Tam Thanh Community Arts Project. This is a place where art works are kept, where artists and can come explore new experiment and save their creations to the community.

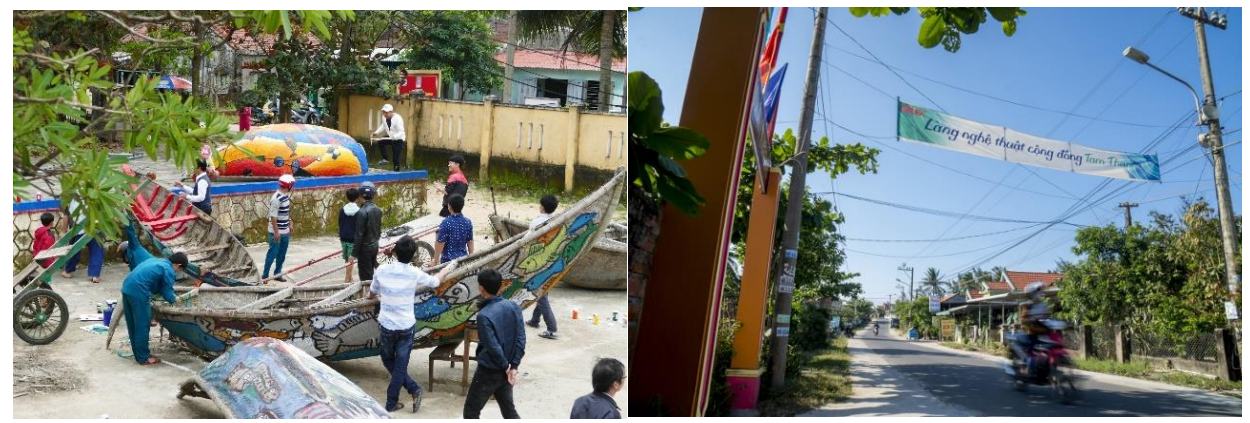

Fig. 5. Community participated in boat painting and decorated village road. Co- Implementing of Tam Thanh.

\section{Discussion}

From all the positive-toward-the-right-targets impacts of the project, Tam Thanh people's awareness has changed significantly. They really want to participate, become more active 
and have a clear sense of changing their own environment and lives. Previously, when given money or home, they not only did not preserve but also deal with it as if it with no respect. Now that they spend money (even if that money is borrowed) they know how to care and really work, how to build utility to best serve tourists, to ensure sustainable income.

All participants: From the experts, university lecturers and students of many universities participating in the project, they also improved the capacity of practicing projects for the community. Through their experience with the community, through the successes of the "bottom up" approach, participants also open up new paths in their field of expertise to undertake more realistic, more effective follow-up projects.

\section{Conclusion}

Experience of Community Design projects:

Collaboration for Success: The support of a dedicated team of volunteer experts / architects from different agencies and organizations helps to increase the self-confidence of the poor in the process of seeking solutions themselves. Solving problems with their own resources

People who are targeted in most of the community projects are often the poorest group, so when implementing a project, stakeholders must understand the correct approach: Bottom up from where people come from. From then on, people who are passively looking for external support will actively participate in changing their own lives. Active empowerment has helped to reduce construction costs and increase community cohesion.

Local government is a very important factor in supporting and facilitating the success of the project: An open minded government able to adopt new ways of doing things, empowering people to set up and implement the plan will be an important factor for the project to be effective.

In order to work well with the community, perseverance and sympathy are needed to build good relationships and trust in the community, as well as requiring each member of the project to be dedicated, responsible, enthusiastic, harmonious and cooperative.

Architects for the community must be aware of their role not as the proponent but as the facilitator for the people to come up with the idea. When considering and evaluating (with the people) the design options, architects must reduce their rationality, consider more humanity, and choose an option that is closer to the community.

\section{References}

1. Le Dieu Anh, Seminar Presentation at community development workshop in Tam Ky (Quang Nam, Vietnam, 2016)

2. N. T. H. Nguyen, Self- help housing for the urban poor in Ancien Quarter (IHS, Hanoi, 1999)

3. N. T. H. Nguyen, Hanoi Women involed in the "Green, Clean and Beautiful City" movement, Seminar presentation in Conference on "Women's Studies Asian Connections" (University of Calgary, Canada, 2000)

4. N. T. H. Nguyen, Resetlement for urban poor in Hanoi's Old Quarter, Presentation in the International Conference on "Architecture and Urbanism of Vietnam" (Seoul National University, Korea, 2005)

5. N. T. H. Nguyen, Design for the community, choosing effective models, Presentation in workshop on "Architecture for the Community" (Vietnam Architecture Association, Vietnam, 2016) 
6. L. N. Nga, What solution for the poorly self-reliant neighborhoods living on public land and along canals? Seminar Presentation at community development workshop in Tam Ky (Quang Nam, Vietnam, 2016)

7. T. Merton, Comprehensive site planning transform community to better living place for all (Asian Coaliton for Housing Right, 2012)

8. Community Mapping for Housing by Peoples Process Handbook (ACHR Secretariat, Bangkok, 2011)

9. S. Kaptein, Community design factors and their infuluence on physical activity in the aging population (A Rapid Review, 2016)

10. A. Ramsbottom, A literature review on community and institutional preparedness synergies: Enablers and barriers in community and institutional preparedness effectively working together globally and specifically within the EU/EEA, Technical report (Stockholm, 2017) 